\title{
Morphological abnormalities in benthic foraminifera caused by an attached epibiont foraminifer
}

\author{
Abduljamiu O. Amao ${ }^{1,2 *}$, Michael A. Kaminski ${ }^{1}$ \& Fabrizio Frontalini ${ }^{3}$ \\ ${ }^{1}$ Geosciences Department, College of Petroleum Engineering and Geosciences, King Fahd University of Petroleum and \\ Minerals (KFUPM), Dhahran 31261, Saudi Arabia \\ ${ }^{2}$ Center for Environment and Water-Marine Section, Research Institute, King Fahd University of Petroleum and Minerals \\ (KFUPM), Dhahran 31261, Saudi Arabia \\ 3 Dipartimento di Scienze Pure e Applicate (DiSPeA), Campus Scientifico, Università degli Studi di Urbino 'Carlo Bo', \\ Località Crocicchia, 61029 Urbino, Italy \\ *Correspondence: amao@kfupm.edu.sa
}

\begin{abstract}
This study focused on the possible 'parasitism-like' relationship between the epibiont Cymbaloporetta sp. and basibiont benthic foraminifera including Agglutinella soriformis El-Nakhal, Adelosina carinatastriata Wiesner, Pseudotriloculina sp. and Spiroloculina indica Cushman \& Todd from a sample collected off the east coast of Bahrain in the Arabian Gulf. There are no indications of preferential host selection, the epibiont seems to attach on to any available basibiont. However, constriction of the test and subsequent growth of the basibiont's chambers at the point of attachment of the epibiont might suggest an early link in their ontogeny. This biotic relationship has implications on the basibionts' development and ontogeny that eventually results in the development of foraminiferal abnormalities. The finding of morphological test abnormalities caused by an epibiont in an unpolluted environment has important implications for the use of the abnormalities for pollution biomonitoring. Samples from other areas of the Arabian Gulf need to be studied in order to determine the background proportion of specimens with epiboints.
\end{abstract}

Keywords: foraminifera, epibionts, basibionts, abnormalities, Arabian Gulf

Received 18 October 2015; revised 31 January 2016; accepted 3 February 2016

Benthic foraminiferal morphological variations and abnormalities are known to be induced by fluctuations in environmental parameters (including changes in carbonate saturation state, temperature, salinity, depth and dissolved oxygen), mechanical damage and pollution (e.g. Boltovskoy et al. 1991; Yanko et al. 1994, 1998; Geslin et al. 2002). Epibionts (epizoic and epiphytic) and bioeroding foraminifera appear to be well documented in the literature (Langer 1993; Langer \& Bagi 1994; Vénec-Peyré 1996) but little is known about their role in formation of morphological abnormalities. This articledocuments a symbiotic relationship between an epibiont, Cymbaloporetta and several basibiont benthic foraminiferal species and the possible induction of morphological abnormalities. Parasitic behaviours and epibiontbasibiont species relationships of foraminiferal taxa have been also documented in the geological record, for instance, during the Late Cretaceous by Talpinella cunicularia (Baumfalk et al. 1982). However, no study on Recent foraminifera has quantitatively assessed this possible morphological abnormality-induction relationship.

Cymbaloporella tabellaeformis has already been inferred to be a parasite (Matteucci 1980). Other foraminiferal parasitic taxa might possibly include Floresina, Rosalina, Fissurina marginata (Montagu) (reported as Entosolenia marginata), Cibicides refulgens de Montfort and Planorbulinopsis parasitica Banner (i.e. Le Calvez 1947; Todd 1965; Banner 1971; Alexander \& DeLaca 1987; Cedhagen 1994; Hallock \& Talge 1994; Nielsen et al. 2002).

\section{Methodology}

\section{Sample location}

The study area is on the eastern coast of Bahrain in the Arabian Gulf (Fig. 1). The Arabian Gulf is notable for extremes in temperature and salinity and provides an excellent natural laboratory to study the interplay between various ecological parameters, more importantly the deterioration of the benthic environment due to rapid urban development and pollution sources (Sheppard et al. 2010). We measured salinity and water temperature for the area between June 2014 and April 2015 and the range recorded was 43-45 ppt and $26-28^{\circ} \mathrm{C}$, respectively. The study area has been described by Arslan et al. (2016), who analysed organic and inorganic pollutants and determined it is a relatively unpolluted site.

\section{Sample collection and processing}

Surficial sediment $(20 \mathrm{ml})$ was collected using a piston syringe that penetrated $2 \mathrm{~cm}$ deep into the sediment. The location is on the foreshore and approximately $100 \mathrm{~m}$ from the coastline, at a water depth of $65 \mathrm{~cm}$ (Fig. 1). The sediment sample was preserved using laboratory-grade ethanol (70\%) with Rose Bengal stain. The sediment was left in the ethanol-Rose Bengal mixture for two weeks before it was washed and wet-sieved through a $63 \mu \mathrm{m}$ mesh sieve. It was dried and then used for benthic foraminiferal specimen picking. The dried sample was sieved through a $125 \mu \mathrm{m}$ mesh sieve and separated into two aliquots with approximately 300 specimens using a microsplitter to ensure statistically representative counts. The analysed sample is part of a larger collection of samples for a temporal and spatial study in the area. Selected specimens were imaged using scanning electron microscopy (SEM). A modified resin embedding technique (Golubic et al. 1970), which is based on two component epoxy resins allowing faster setting of the resin and limiting the penetration into the foraminiferal test, was used. The resin casts were further ground on a smooth glass with abrasive powder (\#1000). After achieving the appropriate length, resin casts were placed in an ultrasonic water bath for $30 \mathrm{~s}$ to remove abrasive 


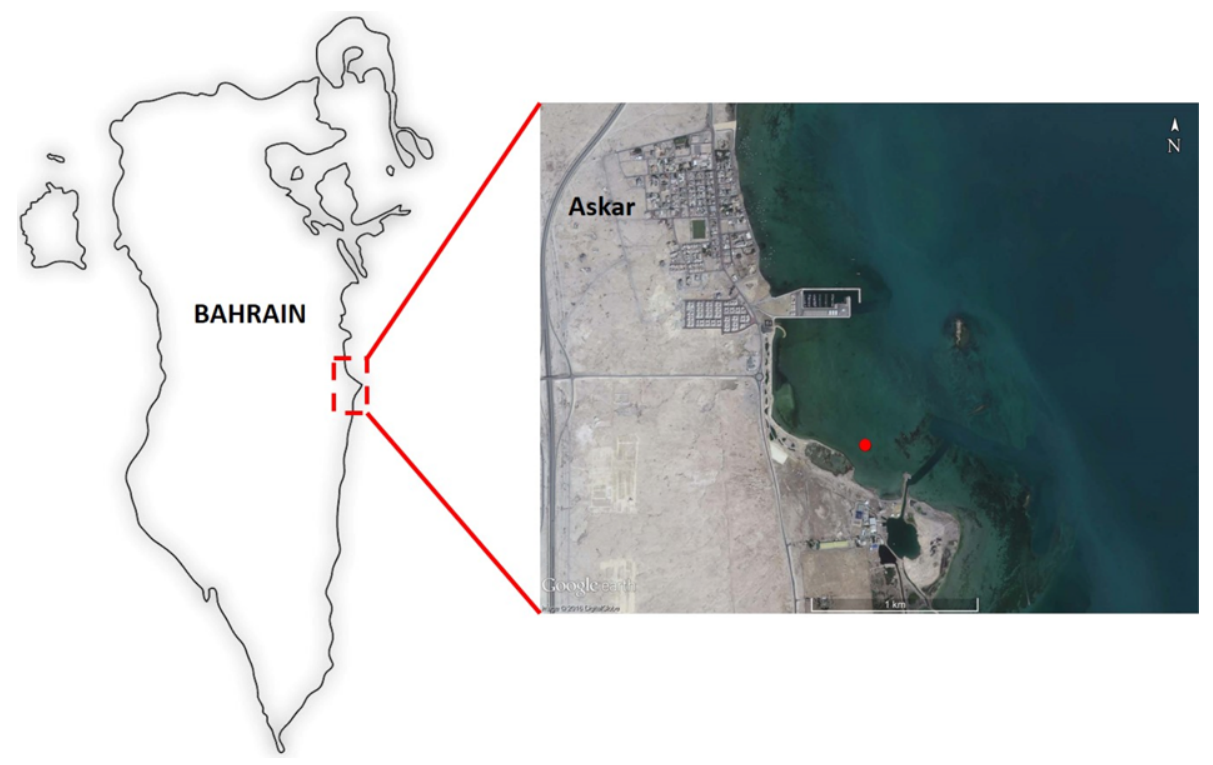

Fig. 1. Location of the sample station indicated by the solid circle on the right image ( $\left.26^{\circ} 02^{\prime} 40.1^{\prime \prime} \mathrm{N}, 50^{\circ} 37^{\prime} 35.2^{\prime \prime} \mathrm{E}\right)$

powder residue and then dried under an incandescent lamp. The resin cast provides support for handling the specimen and produces the desired precise smoothness. The faunal reference slides are currently housed in the authors' collection at KFUPM; these will be permanently archived in the European Micropaleontological Reference Center at Micropress Europe in Kraków (Poland).

\section{Results}

Foraminiferal specimens ( $1.94 \%$ or 11 out of 567 specimens) exhibit varying degrees of morphological abnormalities as a possible result of a symbiotic association between an attached epibiont foraminifer and its basibiont foraminiferal host. SEM images revealed test morphological abnormalities found at spots characterized by the exclusively occurrence of the epibiont Cymbaloporetta sp. (Fig. 2). The host species include Agglutinella soriformis El-Nakhal, 1983 (Fig. 3a-c), Adelosina carinatastriata Wiesner, 1923 (Fig. 3d-f), Pseudotriloculina sp. (Fig. 3g-i) and Spiroloculina indica Cushman \& Todd, 1944 (Fig. 3j-1) and most of them show various degrees of morphological abnormalities. The apertural view of A. soriformis (Fig. 3a), on the more evolute side, shows the stunted growth of the middle chamber, i.e. Cymbaloporetta sp. is attached on the chamber as opposed to having been 'agglutinated' by the basibiont. Adelosina carinatastriata (Fig. 3d-f) is severely malformed, with the epibiont deeply embedded within the test of the basibiont and likely promoting the

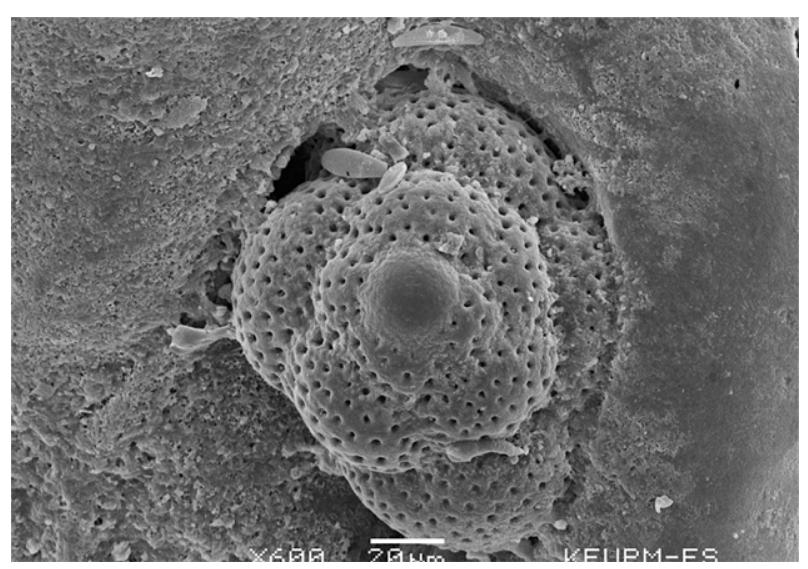

Fig. 2. Cymbaloporetta sp. embedded in the wall of Adelosina carinatastriata Wiesner, 1923. modification of the shape and coiling directions of all the chambers. Pseudotriloculina sp. (Fig. 3g-i) appears to have accommodated the epibiont with minor modification. In $S$. indica (Fig. 31), on the more evolute side, there is an abrupt change in the direction of the final chamber, with the epibiont embedded towards the posterior end. Cross-sections taken at two planes through $A$. carinatastriata (Fig. $4 \mathrm{a}-\mathrm{c}$ ) show test abnormalities as a result of the host accommodation of the epibiont. Agglutinella soriformis (Fig. 4d-f) also exhibits abnormal chambers at the point of epibiont attachment.

\section{Systematic descriptions}

Genus Cymbaloporetta Cushman

Cymbaloporetta cf. C. bradyi (Cushman, 1915)

(Fig. 2)

1915 Cymbalopora poeyi (d'Orbigny) var. bradyi Cushman: 25, pl. 10, fig. 2; pl. 14, fig. 2.

2012 Cymbaloporetta bradyi (Cushman); Debenay: 236, 316 (with synonyms)

Description. Test convex on spiral side, trochospiral, peripheral margin rounded, chambers become bigger as added, first trochospirally arranged later added in an annular arrangement, irregularly globular on the spiral side. Wall coarsely perforated on the spiral side except on earliest chamber. Sutures depressed on both sides; curved on spiral side.

Genus Agglutinella El-Nakhal Agglutinella soriformis El-Nakhal, 1983

(Fig. 3a-c)

1983 Agglutinella soriformis El-Nakhal: 130, pI. 1, figs 7-9, pl. 2, figs $16-18$.

1993 Agglutinella soriformis El-Nakhal; Höttinger et al.: pl. 30, figs $7-10$, pl. 31 , figs $1-4$.

Description. Test broadly subelliptical in lateral view, polygonal in end view, laterally slightly compressed. Chambers U-shaped in section, initially arranged in distinct quadriloculine and later in a triloculine manner. Aboral end of chamber strongly overlaps preceding chamber. Aperture terminal, broadly drop-shaped, bordered by peristomal lip and provided with a spur-shaped bifid tooth with a long base. Wall porcelaneous with a coarsely agglutinated outer layer. 


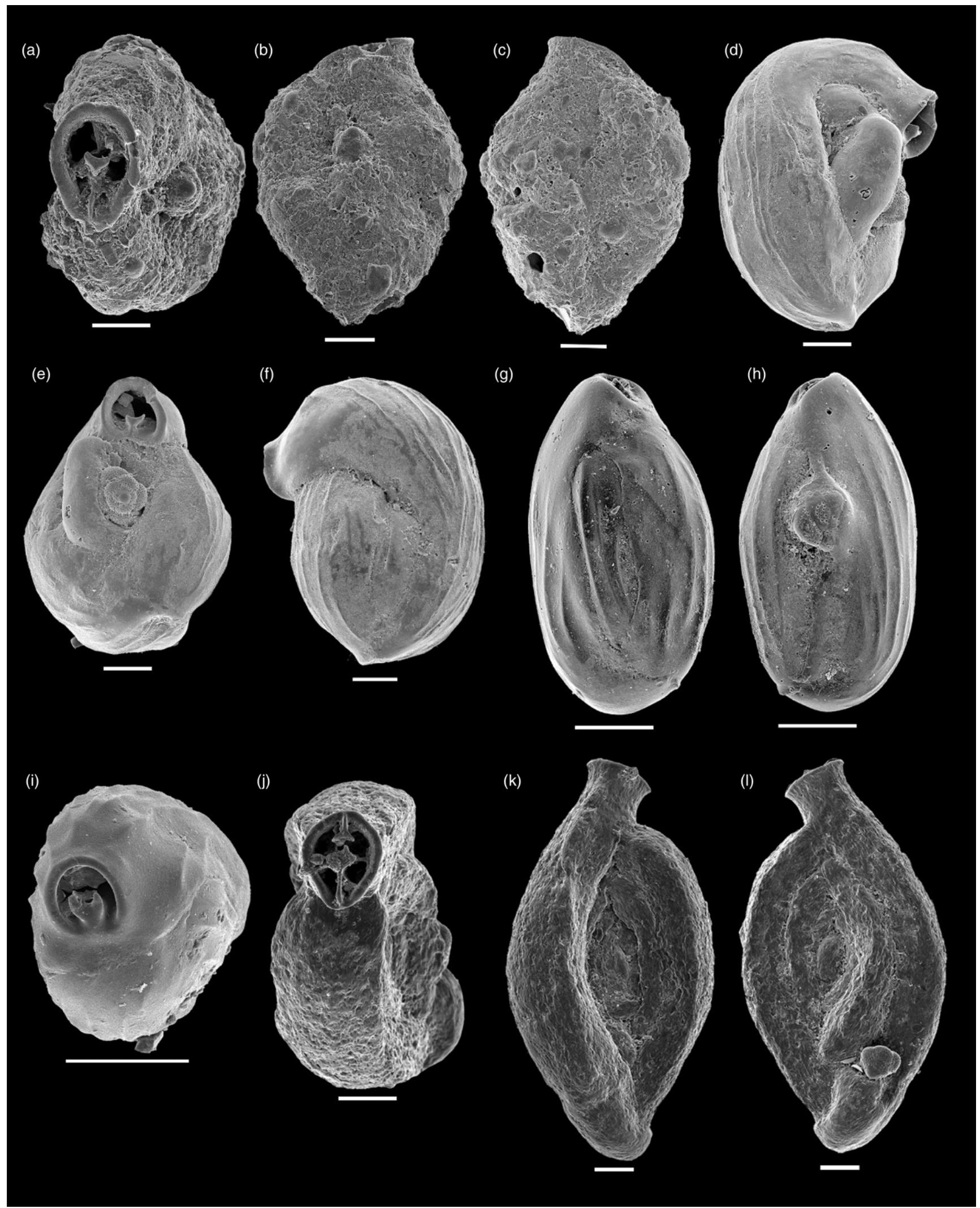

Fig 3. (a-c) Agglutinella soriformis El-Nakhal, 1983: (a) apertural view, (b) lateral view of more evolute side, (c) lateral view of more involute side. (d-f) Adelosina carinatastriata Wiesner, 1923: (d) lateral view of more evolute side, (e) apertural view, (f) lateral view of more involute side. (g-i)

Pseudotriloculina sp.: (g) lateral view of more evolute side, (h) lateral view of more involute side, (i) apertural view. (j-l) Spiroloculina indica Cushman \& Todd, 1944: (j) apertural view, (k) lateral view, (l) lateral view opposite side of (k) with attached epibiont. All scale bars are $100 \mu \mathrm{m}$.

Genus Adelosina d'Orbigny

Adelosina carinatastriata Wiesner, 1923

(Fig. 3d-f)
1923 Adelosina milletti Wiesner var. carinata-striata Wiesner: 7677, pl. 14, figs 190, 191.

2005 Adelosina carinatastriata Wiesner; Debenay, Millet \& Angelidis: pl. 1, fig. 15. 


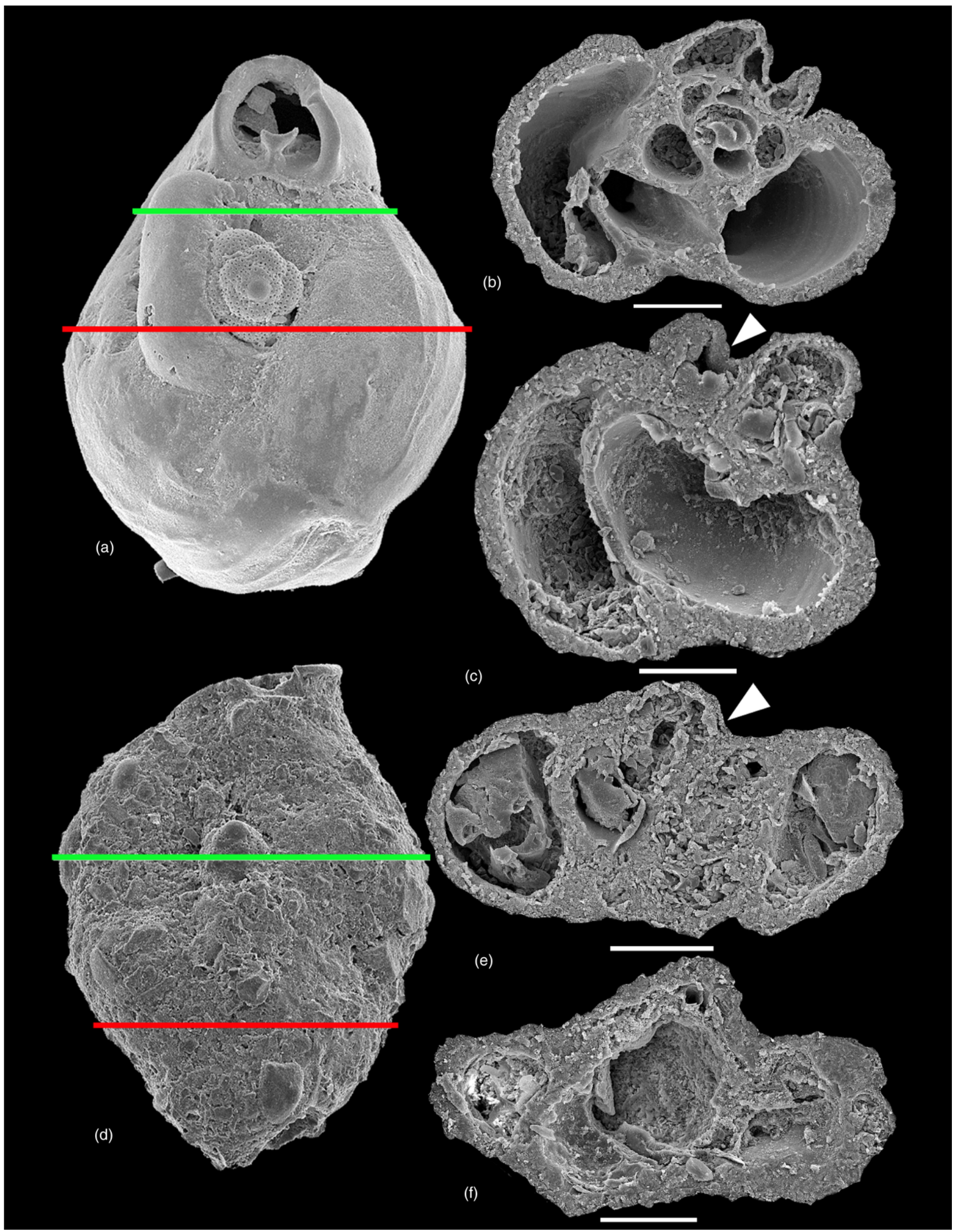

Fig. 4. (a-c) Adelosina carinatastriata: (a) the two lines depict the cross-sections shown in (b) and (c); (b) the anterior part, indicated by the green/upper line on (a); (c) the posterior part, indicated by the red/lower line in (a). (d-f) Agglutinella soriformis: (d) the two lines depict the cross-sections shown in (e) and (f); (e) the anterior part, indicated by the green/upper line on (d); (f) the posterior part, indicated by the red/lower line on (d). Inserted solid white arrows in (c) and (e) point towards the epibiont attachment. All scale bars where provided are $100 \mu \mathrm{m}$. 
Description. Test quinqueloculine, oval in outline, numerous costae run obliquely along the chambers and unite peripherally. The aperture is terminal, at the end of a short neck, bordered by a small peristomal rim, with a small bifid tooth.

\section{Genus Pseudotriloculina Cherif Pseudotriloculina sp.}

(Fig. 3g-i)

1993 Pseudotriloculina sp. B. Höttinger et al.: pl. 49, figs 1-7.

Description: Test porcelaneous, elongate, narrow elliptical in lateral view. Chambers arranged in a quadriloculine manner, sutures rather indistinct. Aperture terminal, rounded, at the end of a distally narrowing extension of the chamber, producing a short, stout neck lacking a distinct lip and provided with a broadly bifid, spoon-like tooth with a very short base.

\section{Genus Spiroloculina d'Orbigny Spiroloculina indica Cushman \& Todd, 1944} (Fig. 3j-1)

1944 Spiroloculina indica Cushman \& Todd: 71, pl. 9, fig. 32. 1993 Spiroloculina indica Cushman \& Todd; Höttinger et al.: pl. 26, figs $10-14$.

Description. Test porcelaneous, biloculine, evolute, fusiform in lateral view, strongly biconcave. The aperture is circular, situated at the end of a stout neck, surrounded by a peristomal lip and provided with two teeth, an anvil-shaped bifid one at the inner margin and a primitive bifid tooth at the outer margin.

\section{Discussion}

The percentages of abnormalities (1.94\%) recorded for all the picked specimens in this study is higher than the $1 \%$ value, which has been suggested as the typical background value representing a natural undisturbed population in previous studies (Yanko et al. 1998; Stouff et al. 1999). During the sample preparation of the cross-section of Agglutinella soriformis (Fig. 4d-f), the internal content appeared pinkish, suggesting that the foraminifera was recently alive. There are no indications of preferential host selection; the epibiont seems to attach on to any available basibiont like $A$. soriformis, Pseudotriloculina sp., A. carinatastriata and $S$. indica. Constriction of the test and subsequent growth of the basibiont's chambers at the point of attachment of the epibiont may suggest an early attachment in their ontogeny. Studies have documented symbiotic feeding relationships (i.e. predation, symbiosis and commensalism) between foraminifera and other organisms (Hallock \& Talge 1994; Nielsen et al. 2002). However, little is known about intraspecific biotic factors, such as parasitism, affecting them. This study, therefore, underlines the importance of biotic factors (such as parasitism) in foraminiferal ecology, which has been previously largely underestimated (Murray 2006). In the Arabian Gulf region, this study may have a direct implication on the determination of foraminiferal abnormality percentages - which have been previously correlated to levels of pollution in marine environments (i.e. Yanko et al. 1998; Frontalini et al. 2009).

\section{Conclusions}

The finding of morphological test abnormalities most likely caused by an epibiont in an unpolluted environment has important implications for the use of the morphological abnormalities for pollution biomonitoring. A possible parasite-host (parasitism) relationship of the epibiont cannot be ruled out. Possible evidence of a parasitic mode of life is inferred from the modification of the host chambers. Cross-sections of A. carinatastriata and A. soriformis show some modifications of host chambers at the point of attachment to accommodate the epibiont. Future studies are needed to separate test abnormalities caused by epibionts from those attributable to different types of pollution and to better constrain the possible parasitic v. epibiont relationship of Cymbaloporetta sp.. Due to the sample size considered in this study there is a need to conducted a systematic study of the area based on additional samples.

\section{Acknowledgements and Funding}

We thank the Deanship of Scientific Research, King Fahd University of Petroleum \& Minerals, for funding the current research through Project IN121028. Also, we would like to thank Irina Polovodova Asteman and an anonymous reviewer for the constructive and useful comments.

\section{Scientific editing by Laia Alegret}

\section{References}

Alexander, S.P. \& DeLaca, T.E. 1987. Feeding adaptations of the foraminiferan Cibicides refulgens living epizoically and parasitically on the Antarctic scallop Adamussium colbecki. The Biological Bulletin, 173, 136-159.

Arslan, M., Kaminski, M.A., Tawabini, B.S., Ilyas, M., Babalola, L.O. \& Frontalini, F. 2016. Seasonal variations, environmental parameters, and standing crop assessment of benthic foraminifera in eastern Bahrain, Arabian Gulf. Geological Quarterly, 60, 24-35.

Banner, F.T. 1971. A new genus of the Planortulinidae, an endoparasite of another foraminifer. Revista Española de Micropaleontología, 3, 113-128.

Baumfalk, Y.A., Fortuin, A.R. \& Mok, R.P. 1982. Talpinella cunicularia n. gen., n. sp., a possible foraminiferal parasite of Late Cretaceous Orbitoides. Journal of Foraminiferal Research, 12, 185-196.

Boltovskoy, E., Scott, D.B. \& Medioli, F.S. 1991. Morphological variations of benthic foraminiferal tests in response to changes in ecological parameters: a review. Journal of Paleontology, 65, 175-185.

Cedhagen, T. 1994. Taxonomy and biology of Hyrrokkin sarcophaga gen. et sp. n., a parasitic foraminiferan (Rosalinidae). Sarsia , 79, 65-82.

Cushman, J.A. 1915. A monograph of the foraminifera of the North Pacific Ocean. Part V. Rotaliidae. United States National Museum Bulletin, 71, 1-81.

Cushman, J.A. 1928. Additional genera of the Foraminifera. Contributions from the Cushman Laboratory for Foraminiferal Research, 4, 1-8.

Cushman, J.A. \& Todd, R. 1944. The genus Spiroloculina and its species. Special Publications Cushman Laboratory for Foraminiferal Research, 11, $1-82$.

Debenay, J.P. 2012. A guide to 1,000 foraminifera from Southwestern Pacific: New Caledonia. IRD Éditions. Publications scientifiques du Muséum, Muséum national d'Histoire naturelle, Paris.

Debenay, J.P., Millet, B. \& Angelidis, M.O. 2005. Relationships between foraminiferal assemblages and hydrodynamics in the Gulf of Kalloni, Greece. Journal of Foraminiferal Research, 35, 327-343.

El-Nakhal, H.A. 1983. Agglutinella, a new miliolid genus (Foraminiferida). Journal of Foraminiferal Research, 13, 129-133.

Frontalini, F., Buosi, C., Da Pelo, S., Coccioni, R., Cherchi, A. \& Bucci, C. 2009. Benthic foraminifera as bio-indicators of trace element pollution in the heavily contaminated Santa Gilla lagoon (Cagliari, Italy). Marine Pollution Bulletin, $\mathbf{5 8}, 858-877$.

Geslin, E., Debenay, J.P., Duleba, W. \& Bonetti, C. 2002. Morphological abnormalities of foraminiferal tests in Brazilian environments: Comparison between polluted and non-polluted areas. Marine Micropaleontology, 45, $151-168$.

Golubic, S., Brent, G. \& Lecampion, T. 1970. Scanning electron microscopy of endolithic algae and fungi using a multipurpose casting-embedding technique. Lethaia, 3, 203-209.

Hallock, P. \& Talge, H.K. 1994. A predatory foraminifer, Floresina amphiphaga, n. sp., from the Florida Keys. Journal of Foraminiferal Research, 24, $210-213$.

Höttinger, L., Halicz, E. \& Reiss, Z. 1993. Recent foraminiferida from the Gulf of Aqaba, Red Sea. Akademi ja Znanosti in Umetnosti Slovenia, Ljubljana.

Langer, M.R. 1993. Epiphytic foraminifera. Marine Micropaleontology, 20, 235-265.

Langer, M.R. \& Bagi, H. 1994. Tubicolous polychaetes as substrates for epizoic foraminifera. Journal of Micropalaeontology, 13, 132-132, http://doi.org/10. $1144 /$ jm.13.2.132

Le Calvez, J. 1947. Les perforations du test de Discorbis erecta (Foraminifère). Bulletin du Laboratoire de Dinard, 24, 1-4.

Matteucci, R. 1980. Osservazioni sul foraminifero endolitico Cymbaloporella tabellaeformis (Brady) nell'Atollo di Male (north Male), Isole Maldive. Geologica Romana, 19, 267-274. 
Murray, J.W. 2006. Ecology and Applications of Benthic Foraminifera. Cambridge University Press, Cambridge.

Nielsen, K.S.S., Collen, J.D. \& Ferland, M.A. 2002. Floresina: a genus of predators, parasites or scavengers? Journal of Foraminiferal Research, 32, 93-95.

Sheppard, C., Al-Husiani, M. et al. 2010. The Gulf: a young sea in decline. Marine Pollution Bulletin, 60, 13-38.

Stouff, V., Geslin, E., Debenay, J.P. \& Lesourd, M. 1999. Origin of morphological abnormalities in Ammonia (foraminifera): studies in laboratory and natural environments. Journal of Foraminiferal Research, 29, 152-170.

Todd, R. 1965. A new Rosalina (Foraminifera) parasitic on a bivalve. Deep Sea Research and Oceanographic Abstracts, 12, 831-837.
Vénec-Peyré, M.T. 1996. Bioeroding foraminifera: a review. Marine Micropaleontology, 28, 19-30.

Wiesner, H. 1923. Die miliolideen der östlichen Adria. Privately printed, PragBubenec.

Yanko, V., Kronfeld, J. \& Flexer, A. 1994. Response of benthic Foraminifera to various pollution sources; implications for pollution monitoring. Journal of Foraminiferal Research, 24, 1-17.

Yanko, V., Ahmad, M. \& Kaminski, M. 1998. Morphological deformities of benthic foraminiferal tests in response to pollution by heavy metals: implications for pollution monitoring. Journal of Foraminiferal Research, 28, 177-200. 